\title{
PSTIOS SOPTIB
}

УДК 633.11:631.526.

\section{Нові сорти пшениці ярої ‘Панянка' та 'Діана'}

\author{
О. А. Демидов, С. О. Хоменко, І. В. Федоренко, М. В. Федоренко, Р. М. Близнюк \\ Миронівський інститут пшениці імені В. М. Ремесла НААН України, с. Центральне, Миронівський р-н, Київська обл., \\ 08853, Україна, e-mail: mwheats@mail.ru
}

Мета. Створити нові конкурентоспроможні сорти пшениці ярої. Методи. Польовий, лабораторний. Результати. За результатами конкурсного сортовипробування виділено лінію пшениці м'якої ярої ‘Лютесценс 07-26', що характеризувалася високими показниками таких ознак, як стійкість проти грибних хвороб, якість зерна (вміст білка 15,0\%), маса 1000 зерен (44,6 г), продуктивність (3,92 т/га), стійкість до вилягання (9 балів). У 2011 р. її було передано на Державне сортовипробування (ДСВ) як сорт ‘Панянка'. Лінія пшениці твердої ярої ‘Леукурум 08-11' мала ряд позитивних ознак: досить високу продуктивність (3,05 т/га), низькорослість (79 см), стійкість проти грибних хвороб та вилягання (9 балів) і була передана у 2011 р. на Державне сортовипробування під назвою 'Діана'. За результатами ДСВ (2012-2014 рр.), у 2015 р. сорти пшениці ярої ‘Панянка' та 'Діана' внесено до Державного реєстру сортів рослин, придатних для поширення в Україні. Висновки. Для господарств лісостепової та поліської зон України створено сорти пшениці м'якої та твердої ярої селекції Миронівського інституту пшениці імені В. М. Ремесла НААН України, що проявляють досить високий потенціал продуктивності та адаптивності до стресових умов. Це свідчить про те, що вирощування вітчизняних сортів пшениці ярої сприятиме формуванню високих і якісних урожаїв зерна.

Ключові слова: пшениця яра, сорт, продуктивність.

\section{Вступ}

Дослідження з селекції основних зернових культур в України та результати практичного впровадження свідчать про значний біологічний потенціал сортів вітчизняної селекції. Тому очевидною є роль наукового підходу до розв'язання проблем підвищення рівня виробництва продукції рослинництва, зокрема пшениці ярої.

За розрахунками вчених НААН України, посівна площа пшениці ярої в країні має становити близько 1 млн га, в т. ч. м'якої 650 тис. га, твердої - 350 тис. га. Якщо пшениці м'якій ярій відводиться роль страхової хлібної культури (на випадок загибелі озимої від несприятливих умов перезимівлі), то

Oleksandr Demydov

https://orcid.org/0000-0002-5715-2908

Svitlana Khomenko

https://orcid.org/0000-0002-6047-7711

Fedorenko Iryna

http://orcid.org/0000-0001-5471-6475

Fedorenko Maryna

https://orcid.org/0000-0002-3021-3643

Blyzniuk Ruslan

https://orcid.org/0000-0002-8645-2539 тверду яру завжди недооцінювали, хоч вона є якісною сировиною для макаронних виробів і круп високої харчової цінності [1]. Вітчизняні сорти пшениці ярої є більш адаптованими до місцевих умов, ніж сорти зарубіжної селекції, які лише в оптимальні за гідротермічними умовами роки наближаються за рівнем продуктивності до національного стандарту, а в посушливіших умовах $€$ неконкурентоспроможними [2].

Основною функцією селекції є створення нових сортів і гібридів сільськогосподарських рослин для збільшення виробництва та поліпшення якості вирощеної продукції [3]. На сучасному етапі основними напрямами в селекції пшениці є підвищення врожайності та якості продукції, стійкості до хвороб, шкідників і несприятливих умов зовнішнього середовища (посухостійкість, стійкість до вилягання тощо), створення сортів, придатних для вирощування за інтенсивними технологіями 3 повною механізацією всіх процесів [4, 5]. Сорти пшениці української селекції є цілком конкурентоспроможними на світовому ринку і за багатьма параметрами господарсько-цінних ознак переважають зарубіжні аналоги [6]. Зокрема, нині у Державному реєстрі сортів 
рослин, придатних для поширення в Україні, налічують 40 сортів пшениці м'якої ярої, з них 18 - української селекції та 11 - пшениці твердої ярої [7]. Потенціал продуктивності сучасних вітчизняних сортів пшениці ярої становить 5-8 т/га, проте реалізується він у виробничих умовах лише на 35-40\%, переважно через недотримання технології вирощування або через використання сортів, які не підходять для конкретної зони [8].

Отже, сорт є одним з основних чинників стабільного виробництва зерна пшениці. Для вирощування пшениці ярої необхідно використовувати сорти, у яких потенціал продуктивності та адаптивності до стресових умов за несприятливих гідротермічних умов вегетації є досить високим.

Мета досліджень - створити нові конкурентоспроможні сорти пшениці ярої.

\section{Матеріали та методика досліджень}

Сорт пшениці ярої досліджували протягом 2008-2011 pр. у лабораторії селекції ярої пшениці Миронівського інституту пшениці (МІП) імені В. М. Ремесла НААН України. Сівбу проводили в оптимальні строки на дослідних полях селекційної сівозміни сівалкою СН-10 Ц, повторність - чотириразова. Площа посівної ділянки - 10 м². За стандарт пшениці м'якої ярої використовували сорт 'Елегія миронівська', твердої ярої 'Харківська 27'. Фенологічні спостереження здійснювали відповідно до загальноприйнятих методик $[9,10]$.

\section{Результати досліджень}

У період проведення досліджень погодні умови відрізнялися від середніх багаторічних показників за температурним режимом, кількістю атмосферних опадів та їхнім розподілом в окремі місяці, що сприяло всебічній оцінці ліній конкурсного сортовипробування.

Основним методом селекції в МІП є внутрішньовидова гібридизація за еколого-географічним і генетичним походженням сортів пшениці ярої з подальшим спрямованим добором елітних рослин. За результатами конкурсного сортовипробування (2008-2011 рр.) виділено лінію пшениці м'якої ярої 'Лютесценс 07-26', отриману від схрещування у 2000 році 'Quattro'/'Рання 93' (комбінація № 00363). Приріст урожайності до стандарту в середньому становив 0,84 т/га (табл. 1).

За роки вивчення у лінії 'Лютесценс 07-26' показники стійкості проти грибних хвороб, якості зерна та маси 1000 зерен, стійкості до вилягання були високими. У 2011 р. вона була передана на Державне сортовипробування (ДСВ) як сорт 'Панянка'. За результатами ДСВ (2012-2014 рр.) сорт 'Панянка' у 2015 р. внесено до Державного реєстру сортів рослин, придатних для поширення в Україні.

Сорт є високоврожайним, інтенсивного типу, його рекомендовано для вирощування в Лісостепу, Поліссі та Степу.

Лінія пшениці твердої ярої 'Леукурум 08-11' перевищувала стандарт на 0,37 т/га в середньому за три роки вивчення (2009-2011 рр.)

Характеристика сорту пшениці м'якої ярої ‘Панянка' ('Лютесценс 07-26')

Таблиця 1 у конкурсному сортовипробуванні (МІП, середнє за 2008-2011 рр.)

\begin{tabular}{|c|c|c|c|c|}
\hline Показник & $\begin{array}{c}\text { Одиниця } \\
\text { виміру }\end{array}$ & $\begin{array}{l}\text { 'Елегія миронівська' - } \\
\text { національний стандарт }\end{array}$ & $\begin{array}{c}\text { ‘Панянка’ } \\
\text { ('Лютесценс 07-26’) }\end{array}$ & $\begin{array}{c}\text { Відхилення від стандарту } \\
\text { 'Елегія миронівська', }\end{array}$ \\
\hline Урожайність & т/га & 3,08 & 3,92 & $+0,84$ \\
\hline Висота рослин & $\mathrm{CM}$ & 81,9 & 81,8 & $-0,1$ \\
\hline Стійкість проти вилягання & бал & 9 & 9 & - \\
\hline Ураження на природному фоні: & & & & \\
\hline борошнистою росою & $\%$ & 5 & 1 & -4 \\
\hline бурою листковою іржею & $\%$ & 0 & 0 & - \\
\hline септоріозом листя & $\%$ & 10 & 5 & -5 \\
\hline Ураження на інфекційному фоні: & & & & \\
\hline борошнистою росою & $\%$ & 15 & 7 & -8 \\
\hline бурою листковою іржею & $\%$ & 7 & 4 & -3 \\
\hline септоріозом листя & $\%$ & 10 & 7 & -3 \\
\hline кореневими гнилями & $\%$ & 3 & 1 & -2 \\
\hline твердою сажкою & $\%$ & 15 & 7 & -8 \\
\hline фузаріозом колоса & $\%$ & 25 & 15 & -10 \\
\hline Період сходи-колосіння & діб & 75 & 75 & - \\
\hline Маса 1000 зерен & $\Gamma$ & 44,5 & 44,6 & $+0,1$ \\
\hline Вміст білка в зерні & $\%$ & 15,9 & 15,0 & $-0,9$ \\
\hline Вміст сирої клейковини & $\%$ & 30 & 39 & +9 \\
\hline Седиментація & мл & 52 & 54 & +2 \\
\hline
\end{tabular}


Характеристика сорту пшениці твердої ярої 'Діана' ('Леукурум 08-11')

у конкурсному сортовипробуванні (МIП, середнє за 2009-2011 рр.)

\begin{tabular}{|c|c|c|c|c|}
\hline Показник & $\begin{array}{l}\text { Одиниця } \\
\text { виміру }\end{array}$ & $\begin{array}{c}\text { 'Харківська 27’ - } \\
\text { національний стандарт }\end{array}$ & $\begin{array}{c}\text { ‘Діана’ } \\
\text { (‘Леукурум 08-11') }\end{array}$ & $\begin{array}{c}\text { Відхилення від стандарту } \\
\text { 'Харківська } 27^{\prime}, \pm\end{array}$ \\
\hline Урожайність & т/га & 2,68 & 3,05 & $+0,37$ \\
\hline Висота рослин & CM & 85 & 79 & -6 \\
\hline Стійкість проти вилягання & бал & 9 & 9 & - \\
\hline Ураження на природному фоні: & & & & \\
\hline борошнистою росою & $\%$ & 10 & 3 & -7 \\
\hline бурою листковою іржею & $\%$ & 3 & 0 & -3 \\
\hline септоріозом листя & $\%$ & 5 & 5 & - \\
\hline Ураження на інфекційному фоні: & & & & \\
\hline борошнистою росою & $\%$ & 5 & 0 & -5 \\
\hline бурою листковою іржею & $\%$ & 7 & 1 & -6 \\
\hline септоріозом листя & $\%$ & 10 & 7 & -3 \\
\hline кореневими гнилями & $\%$ & 5 & 5 & - \\
\hline твердою сажкою & $\%$ & 0 & 0 & - \\
\hline фузаріозом колоса & $\%$ & 10 & 3 & -7 \\
\hline Період сходи-колосіння & діб & 71 & 75 & +4 \\
\hline Маса 1000 зерен & $\Gamma$ & 45,2 & 43,5 & $-1,7$ \\
\hline
\end{tabular}

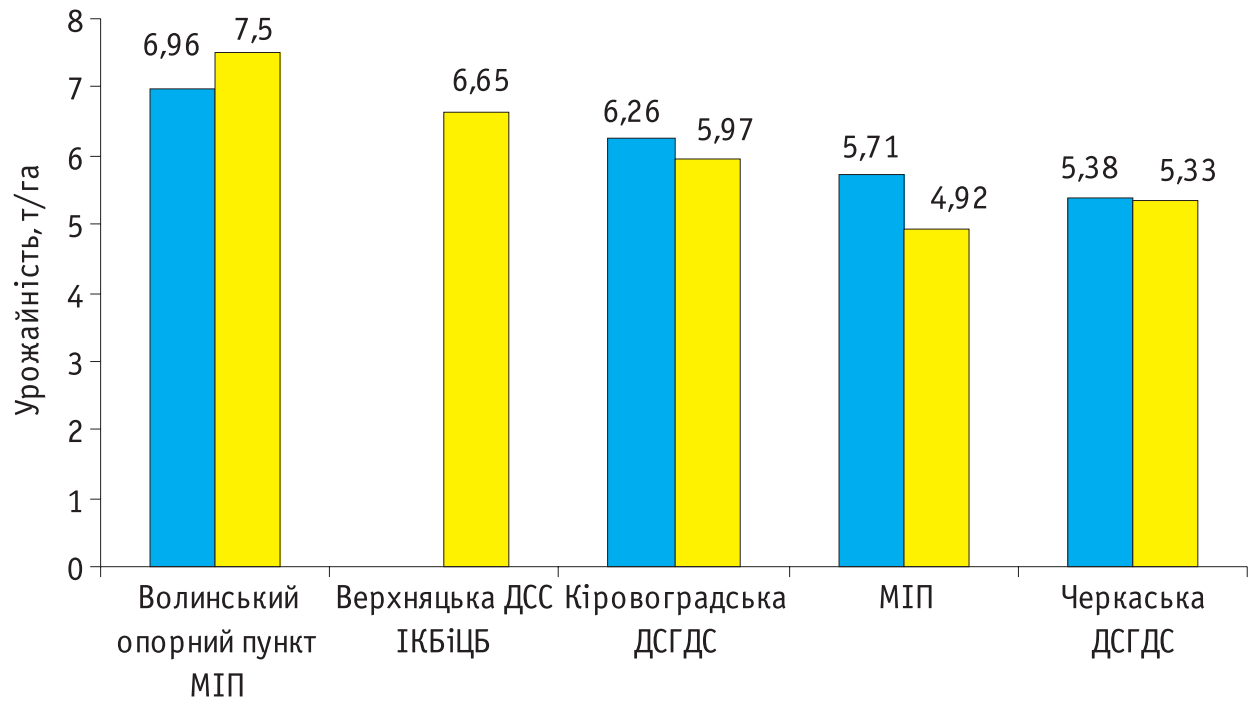

Рис. Урожайність сортів пшениці ярої ‘Панянка' та 'Діана' на демонстраційних полігонах України (2015р.)

у конкурсному сортовипробуванні, характеризувалася рядом позитивних ознак і була передана у 2011 р. на Державне сортовипробування під назвою 'Діана' (табл. 2).

Лінію отримано від міжвидового озимоярого схрещування у 1999 р. 'Миронівська 808’ (PРD1)/“Кієвлянка’ (комбінація № 9991) у групі мутагенезу лабораторії селекції інтенсивних сортів озимої пшениці. За результатами ДСВ (2012-2014 рр.), сорт 'Діана' з 2015 р. внесено до Державного реєстру сортів рослин, придатних для поширення в Україні. Рекомендовано для вирощування в Лісостепу та Поліссі. Сорт напівінтенсивного типу.

У 2015 р. сорти миронівської селекції були представлені на різних демонстраційних полігонах України (див. рисунок).

\section{Висновки}

Для господарств лісостепової, поліської зон України створено сорт пшениці м'якої ярої 'Панянка' та твердої ярої 'Діана' селекції МІП, що відповідають сучасним загальним вимогам: є досить стійкими проти вилягання, осипання та проростання зерна в колосі, мають вище середньої стійкість проти основних грибних хвороб (борошнистої роси, бурої листкової іржі, септоріозу листя, кореневих гнилей, твердої сажки та фузаріозу колоса), за несприятливих гідротермічних умов вегетації проявляють досить високий потенціал продуктивності та адаптивності до стресових умов. Таким чином, вирощування вітчизняних сортів пшениці ярої 
сприятиме формуванню високих та якісних урожаїв зерна.

\section{Використана літератури}

1. Рослинництво з основами кормовиробництва / С. М. Каленська, М. Я. Дмитришак, Г. І. Демидась [та ін.]. - Вінниця : Нілан, 2014. - 649 с.

2. Методические рекомендации по определению потенциальной и реальной продуктивности пшеницы / Ф.М.Куперман, В. В. Мурашёв, И. П. Щербина [и др.]. - М. : Изд-во ВАСХНИЛ, 1980. -40 C.

3. Медведовський 0. К. Енергетичний аналіз інтенсивних технологій в сільськогосподарському виробництві / 0. К. Медведовський, П. І. Іваненко. - К. : Урожай, 1988. - 208 с.

4. Лихочвор В. В. Рослинництво. Сучасні інтенсивні технології вирощування основних польових культур / В. В. Лихочвор, В. Ф. Петриченко. - Львів : Українські технології, 2006. - 730 С.

5. Лихочвор В. В. Зерновиробництво / В. В. Лихочвор, В. Ф. Петриченко, П. В. Іващук. - Львів : Українські технології, 2006. -730 c.

6. Жемела Г. М. Якість зерна озимої пшениці / Г. П. Жемела. К. : Урожай, 2003. - 183 с.

7. Державний реєстр сортів рослин, придатних для поширення в Україні у 2016 році [Електронний ресурс]. - Режим доступу : http://vet.gov.ua/sites/default/files/reestr\%2014.04.2016.pdf

8. Николаев Е. В. Резервы увеличения производства зерна сильной и ценной пшеницы / Е. В. Николаев. - К. : Урожай, 1991. - 232 с.

9. Методика державного сортовипробування сільськогосподарських культур. Вип. 1. Загальна частина / ред. В. В. Волкодав ; Держ. коміс. України по випробуванню та охороні сортів рослин. - К. : [б. в.], 2000. - 100 с.

10. Методы селекции и оценки устойчивости пшеницы и ячменя к болезням в странах-членах СЭВ / Л. Т. Бабаянц, А. Мештерхази, Ф. Вехтер [и др.]. - Прага : [б. и.], 1988. - 322 с.

\section{References}

1. Kalenska, S. M., Dmytryshak, M. Ya., Demydas, H. I., Mokriienko, V. A., Yunyk, R. V., \& Kovalenko, R. V. (2014). Roslynnytstvo z osnovamy kormovyrobnytstva [Plant growing with the basics of forage production]. Vinnytsia: Nilan. [in Ukrainian]

2. Kuperman, F. M., Murashev, V. V., Shcherbina, I. P., Ananyeva, L. V., Yaroshevskaya, A. S., \& Bykova, M. S. (1980). Metodicheskie rekomendatsii po opredeleniyu potentsialnoy $i$ realnoy produktivnosti pshenitsy [Guidelines for evaluation of the potential and real productivity of wheat]. Moscow: VASKhNIL. [in Russian]

3. Medvedovskyi, 0. K., \& Ivanenko, P. I. (1988). Enerhetychnyi analiz intensyvnykh tekhnolohii $v$ silskohospodarskomu vyrobnytstvi [Energy analysis of intensive technologies in agriculture]. Kyiv: Urozhai. [in Ukrainian]

4. Lykhochvor, V. V., \& Petrychenko, V. F. (2006). Roslynnytstvo. Suchasni intensyvni tekhnolohii vyroshchuvannia osnovnykh polovykh kultur [Plant growing. Modern intensive technologies of cultivation of staple crops]. Lviv: Ukrainski tekhnolohii. [in Ukrainian]

5. Lykhochvor, V. V., Petrychenko, V. F., \& Ivashchuk, P. V. (2006). Zernovyrobnytstvo [Grain production]. Lviv: Ukrainski tekhnolohii. [in Ukrainian]

6. Zhemela, G. M. (2003). Yakist zerna ozymoi pshenytsi [Quality of winter wheat grain]. Kyiv: Urozhai. [in Ukrainian]

7. Derzhavnyi reiestr sortiv roslyn, prydatnykh dlia poshyrennia $v$ Ukraini v 2016 rotsi [State Register of plant varieties suitable for dissemination in Ukraine in 2016]. (2016). Retrieved from http://vet.gov.ua/sites/default/files/reestr\%2014.04.2016. pdf [in Ukrainian]

8. Nikolaev, E. V. (1991). Rezervy uvelicheniya proizvodstva zerna silnoy i tsennoy pshenitsy [Reserves to increase the production of strong and valuable wheat grain]. Kiev: Urozhai. [in Russian]

9. Volkodav, V. V. (Ed.). (2000). Metodyka derzhavnoho sortovyprobuvannia silskohospodarskykh kultur. Vypusk 1. Zahalna chastyna [Methods of State variety testing of agricultural crops. Issue 1. General part]. Kyiv: N.p. [in Ukrainian]

10. Babaiants, L., Mesterhazy, A., Wachter, V., Neklesa, N., Dubinina, L., Omelchenko, L., ... \& Bartosh, P. (1988). Metody selektsii $i$ otsenki ustoychivosti pshenitsy $i$ yachmenya $k$ boleznyam $v$ stranakh-chlenakh SEV [Methods of Breeding and Evaluating Wheat and Barley for Resistance to Disease in COMECON countries]. Prague: N.p. [in Russian]

\section{УДК 633.11:631.526.32}

Демидов А. А., Хоменко С. О., Федоренко И. В., Федоренко М. В., Блызнюк Р. Н. Новые сорта пшеницы яровой ‘Панянка' и 'Диана' // Сортовивчення та охорона прав на сорти рослин. - 2016. - № 4. - С. 82-86.

Мироновский институт пшеницы им. В. М. Ремесло НААН Украины, с. Центральное, Мироновский р-н, Киевская обл., 08853, украина, е-mail:mwheats@mail.ru

Цель. Создать новые конкурентоспособные сорта пшеницы яровой. Методы. Полевой, лабораторный. Результаты. По результатам конкурсного сортоиспытания выделена линия пшеницы мягкой яровой 'Лютесценс 07-26', которая характеризовалась высокими показателями таких признаков, как устойчивость против грибных болезней, качество зерна (содержание белка 15,0\%), масса 1000 зерен (44,6 г), продуктивность (3,92 т/га), устойчивость к полеганию (9 баллов). В 2011 г. она была передана на Государственное сортоиспытание (ГСИ) как сорт 'Панянка'. Линия пшеницы твердой яровой 'Леукурум 08-11' имела ряд положительных признаков: достаточно высокую продуктивность $(3,05 \mathrm{~T} /$ га), низкорослость $(79$ см), устойчивость против грибных болезней и полегания (9 баллов) и была передана в 2011 г. на Государственное сортоиспытание под названием 'Диана'. По результатам ГСИ (2012-2014 гг.), в 2015 г. сорта пшеницы яровой 'Панянка' и 'Диана' внесены в Государственный реестр сортов растений, пригодных для распространения в Украине. Выводы. Для хозяйств лесостепной и полесской зон Украины созданы сорта пшеницы мягкой и твердой яровой селекции Мироновского института пшеницы имени В. М. Ремесло НААН Украины, которые проявляют достаточно высокий потенциал продуктивности и адаптивности к стрессовым условиям. Это свидетельствует о том, что выращивание отечественных сортов пшеницы яровой будет способствовать формированию высоких и качественных урожаев зерна.

Ключевые слова: пшениця яровая, сорт, продуктивность. 


\section{UDC 633.11:631.526.32}

Demydov, 0. A., Khomenko, S. O., Fedorenko, I. V., Fedorenko, M. V., \& Blyzniuk, R. M. (2016). New spring wheat varieties 'Panianka' and 'Diana'. Sortovivčennâ ohor. prav sorti roslin [Plant Varieties Studying and Protection], 4, 82-86.

The V. M. Remeslo Myronivka Institute of Wheat of NAAS of Ukraine, Tsentralne village, Myronivka district, Kyiv region, 08853, Ukraine, e-mail:mwheats@mail.ru

Purpose. To create new competitive spring wheat varieties. Methods. Field study, laboratory test. Results. Based on the competitive variety trial, bread spring wheat line 'Lutescens $07-26$ ' has been selected due to high values of such traits as resistance to fungal diseases, grain quality (protein content accounted for $15.0 \%$ ), 1000 kernel weight $(44.6 \mathrm{~g})$ productivity $(3.92 \mathrm{t} / \mathrm{ha})$ and lodging resistance (9 points). In 2011, it was submitted to the State variety testing as 'Panianka' variety. Durum spring wheat line 'Leukurum 08-11' was characterized by a number of positive traits: quite a high productivity (3.05 t/ha), short stem $(79 \mathrm{~cm})$, resistance to fungal diseases and lodging (9 points), and in 2011 it was submitted to the State vari- ety testing as 'Diana' variety. According to the results of the State variety testing in 2012-2014, spring wheat varieties 'Panianka' and 'Diana' in 2015 were put on the State Register of plant varieties suitable for dissemination in Ukraine. Conclusions. For farms in Forest-Steppe and Polissia zones of Ukraine, bread and durum spring wheat varieties were bred by V. M. Remeslo Myronivka Institute of Wheat of NAAS of Ukraine that demonstrated rather high potential of productivity and adaptability to stress conditions. This goes to prove that cultivation of domestic spring wheat varieties will promote formation of high and quality grain yields.

Keywords: spring wheat, variety, productivity.

Надійшла 8.08.2016 